\title{
Ultrafine Ni-B nanoparticles for efficient hydrogen evolution reaction
}

\author{
Ting Huang, Tao Shen, Mingxing Gong, Shaofeng Deng, Chenglong Lai, Xupo Liu, Tonghui Zhao, \\ Lin Teng, Deli Wang *
}

Key Laboratory of Material Chemistry for Energy Conversion and Storage (Huazhong University of Science and Technology), Ministry of Education, Hubei Key Laboratory of Material Chemistry and Service Failure, School of Chemistry and Chemical Engineering, Huazhong University of Science and Technology, Wuhan 430074, Hubei, China

\section{A R T I C L E I N F}

Article history:

Received 27 January 2019

Accepted 4 March 2019

Published 5 December 2019

\section{Keywords:}

$\mathrm{Ni}-\mathrm{B}$

Non-noble electrocatalyst

Hydrogen evolution reaction

Ultrafine nanoparticle

Alkaline electrolyte

\begin{abstract}
A B S T R A C T
The search for active, stable, and cost-effective electrocatalysts for hydrogen evolution reaction (HER) is desirable, but it remains a great challenge in the overall water splitting. Here, we report the synthesis of nickel boron nanoparticles supported on Vulcan carbon (Ni-B) via a simple, yet scalable, two-step chemical reduction-annealing strategy. The results of the electrochemical measurements suggest that the overpotentials of $\mathrm{Ni}-\mathrm{B}-400$ are 114 and $215 \mathrm{mV}$ (in $1 \mathrm{~mol} \mathrm{~L}^{-1} \mathrm{KOH}$ ) at current densities of 10 and $40 \mathrm{~mA} \mathrm{~cm}^{-2}$, respectively, indicating an exceedingly good electrocatalytic activity in the HER. More importantly, Ni-B maintains a current density of $7.6 \mathrm{~mA} \mathrm{~cm}^{-2}$ at an overpotential of $0.15 \mathrm{~V}$ for $20 \mathrm{~h}$ in the durability test. The excellent HER activity of Ni-B-400 is derived from the small particle size and the expanded lattice of $\mathrm{Ni}$, which can optimize the hydrogen absorption energy and enhance the electrocatalytic properties.
\end{abstract}

(C) 2019, Dalian Institute of Chemical Physics, Chinese Academy of Sciences. Published by Elsevier B.V. All rights reserved.

\section{Introduction}

The electrolysis of water by hydroelectric power or solar electrical energy is an environmentally friendly method to produce high-purity hydrogen [1]. However, due to the sluggish reaction kinetics during the electrolysis of water, electrocatalysts are needed to improve the reaction rate and efficiency of the electrocatalytic hydrogen and oxygen production [2-5]. Precious metals generally have better activities and stabilities in the hydrogen evolution reaction (HER) [6], but the low reserves and high price limit the large-scale application of the precious metals [7-9]. Therefore, it is important to develop a catalyst that has abundant reserves, low price, and high activity and stability. Nickel-based materials exhibit platinoid electronic structure, are low priced, and have abundant reserves [10], which have attracted much attention, in combination with nonmetals such as Ni-O [11,12], Ni-P [13,14], Ni-S [15,16], and Ni-B $[17,18]$, for HER. These nonmetallic dopants play a pivotal role in improving the catalytic activity and efficiency of the electrocatalytic hydrogen production by adjusting the electronic structure of the catalyst surface. The structure-activity relationship of these materials is becoming clearer from the investigations by a vast number of researchers. The strong electron affinity of $\mathrm{S}$ and $\mathrm{O}$ leads to a significant decrease in the electron density on $\mathrm{Ni}$, which is not conducive for the adsorption of $\mathrm{H}$. On the other hand, the weak electron affinity of $\mathrm{P}$

\footnotetext{
* Corresponding author. E-mail: wangdl81125@hust.edu.cn

This work was supported by the National Natural Science Foundation of China (21573083), the 1000 Young Talent (to Deli Wang), and initiatory financial support from Huazhong University of Science and Technology (HUST). The authors thank the Analytical and Testing Center of HUST for allowing use of its facilities.

DOI: S1872-2067(19)63331-0 | http://www.sciencedirect.com/science/journal/18722067 | Chin. J. Catal., Vol. 40, No. 12, December 2019
} 
leads to a high electron density on $\mathrm{Ni}$, which is not conducive for the adsorption of water and hydroxide. In this regard, although Ni-B has a unique electronic structure [19-23], research on its effect in the hydrogen evolution is rare, and thus, its structure-activity relationship is worth exploring. Herein, Ni-B electrocatalysts were synthesized by a chemical reduction-annealing process (Fig. 1). Ultrafine Ni-B nanoparticles possess more active sites and higher activity. After the annealing treatment, amorphous Ni-B is transformed into Ni-B crystals, resulting in lattice expansion and a good electrocatalytic hydrogen evolution activity.

\section{Experimental}

\subsection{Preparation of Ni-B catalysts}

$\mathrm{Ni}$-B catalyst was prepared by the chemical reduction method. Vulcan XC-72 (0.3 g) and $\mathrm{NiCl}_{2} \cdot 6 \mathrm{H}_{2} \mathrm{O}(0.81 \mathrm{~g})$ were dispersed into a $50 \mathrm{~mL}$ ethylene glycol solution. After stirring for $5 \mathrm{~min}$ and sonicating for $25 \mathrm{~min}$, the solution was placed in an ice bath for cooling and stirred. Then, $50 \mathrm{~mL} \mathrm{NaBH}_{4}$ solution ( $0.01 \mathrm{~g} \mathrm{~mL}^{-1}$ ) was added dropwise into it. When the solution stopped bubbling, the mixture was centrifuged and washed thrice with deionized water. Ni-B was obtained after freeze-drying. The obtained materials were annealed at 200, 300,400 , and $500{ }^{\circ} \mathrm{C}$ for $2 \mathrm{~h}$ in an argon atmosphere to obtain Ni-B-200, Ni-B-300, Ni-B-400, and Ni-B-500, respectively.

\subsection{Physicochemical characterization of Ni-B catalysts}

$\mathrm{X}$-ray diffraction (XRD) patterns of the Ni-B samples were recorded on an X'Pert PRO diffractometer from $15^{\circ}$ to $85^{\circ}$ at a sweep rate of $10^{\circ} \mathrm{min}^{-1}$. Transmission electron microscopy (TEM) images were captured on an FEI-Talos transmission electron microscope. X-ray photoelectron spectroscopy (XPS) data were recorded on an AXIS-ULTRA DLD-600W spectrometer. Thermal gravimetric analysis (TGA) was carried out on TA Q500 instrument under flowing air at a heating rate of $10{ }^{\circ} \mathrm{C}$ $\mathrm{min}^{-1}$. Inductively coupled plasma-atomic emission spectroscopy (ICP-AES) was carried out on an IRIS Advantage (Thermo Elemental Co. USA) spectrometer to obtain the composition of

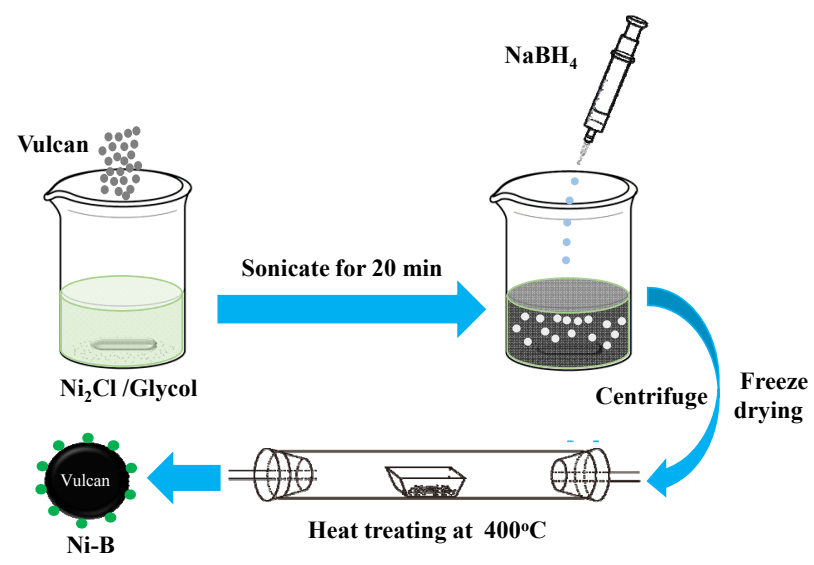

Fig. 1. Schematic diagram of the synthesis of Ni-B-400 catalyst. the catalyst.

\subsection{Electrochemical performance}

All the electrochemical measurements of $\mathrm{Ni}-\mathrm{B}$ samples were conducted in a typical three-electrode system in $1 \mathrm{~mol} \mathrm{~L}^{-1} \mathrm{KOH}$ solution on an Autolab PG302N Potentiostat/Galvanostat. Glassy carbon electrode (GCE, diameter: $5 \mathrm{~mm}$ ) coated with sample was used as the working electrode, a graphite rod and a reversible hydrogen electrode (RHE) served as the counter electrode and reference electrode, respectively. Catalyst samples (5 mg) were dispersed in $1 \mathrm{~mL}$ Nafion/isopropanol hybrid solution (1 wt\%) by sonication to form a homogeneous ink. Then, $16.5 \mu \mathrm{L}$ ink was loaded onto the GCE (catalyst loading: $0.168 \mathrm{mg} \mathrm{cm}^{-2}$ ).

Linear sweep voltammograms (LSVs) were recorded from 0.2 to $-0.4 \mathrm{~V}$ at a scan rate of $5 \mathrm{mV} \mathrm{s}^{-1}$ in $\mathrm{H}_{2}$-saturated electrolytes at $25^{\circ} \mathrm{C}$. The double-layer capacitances were obtained by utilizing the cyclic voltammograms from 0.2 to $0.4 \mathrm{~V}$ at scan rates ranging from 20 to $200 \mathrm{mV} \mathrm{s}^{-1}$. The LSV test was conducted after repeating the potential scan for 3000 cycles in the range between 0.2 and $-0.2 \mathrm{~V}$ on the carbon cloth. The durability was tested at a constant cathode potential of $150 \mathrm{mV}$ for 20 h. All the electrochemical data were original, without any corrections.

\section{Results and discussion}

Fig. 2a illustrates the XRD patterns of the Ni-B catalysts. It shows a wide and weak peak at around $45^{\circ}$ for the Ni-B sample without calcination, indicating an amorphous structure. The peak at around $25^{\circ}$ is mainly the crystalline plane, (002), of the C material [24]. After the annealing treatment, all the four samples show three distinct diffraction peaks at approximately $45^{\circ}$, $52^{\circ}$, and $76^{\circ}$, which are indexed to (111), (200), and (220) characteristic diffractions, respectively, of Ni (JCPDS87-0712). Specifically, the positions of the diffraction peaks shift slightly to the lower angles as the temperature increases (Fig. 2b), indicating a slight expansion of the Ni lattice (Table S1). According to the previous report [20], the lattice expansion is strengthened as the calcined temperature increases. Meanwhile, the peak intensity also gradually increases, suggesting that the particle size of Ni-B gradually increases. The particle sizes of the samples were calculated to be 8.6, 10.0, 15.4, and $18.5 \mathrm{~nm}$ for Ni-B-200, Ni-B-300, Ni-B-400, and Ni-B-500, respectively, according to the Scherrer equation [25].

TEM characterization was utilized to better understand the morphologies and size distributions of the prepared Ni-B catalysts. The Ni-B particles are uniformly loaded on the carbon support (Fig. 3a, Fig. S1, and Fig. S2). The average particles sizes are calculated to be about 9.0,11.0, 16.4, 17.9, and $20.6 \mathrm{~nm}$ for Ni-B, Ni-B-200, Ni-B-300, Ni-B-400, and Ni-B-500, respectively, based on the statistics of more than 200 nanoparticles. The particle sizes increase with increasing temperature because of aggregation at high temperature [26-28], which is consistent with the sizes calculated from the XRD patterns using the Scherrer equation. 

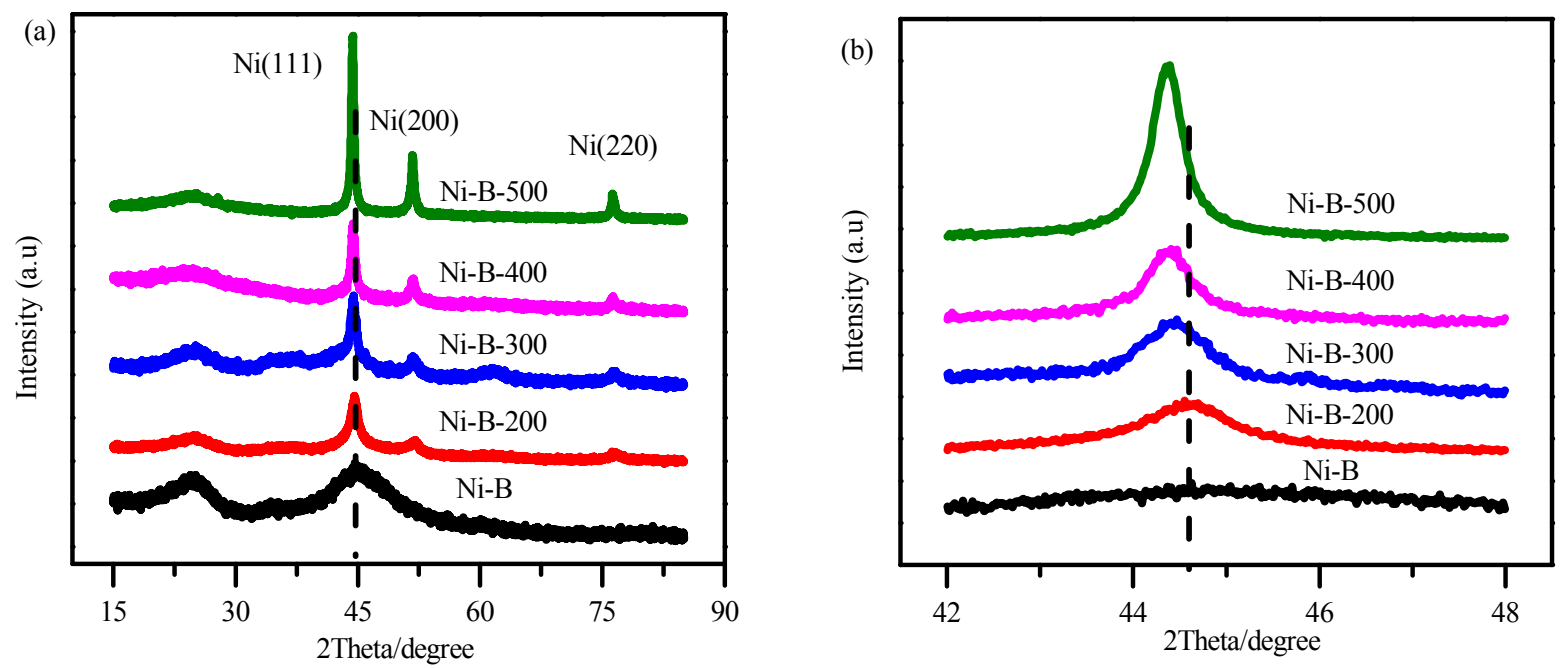

Fig. 2. (a) XRD patterns of Ni-B, Ni-B-200, Ni-B-300, Ni-B-400, and Ni-B-500; (b) Expanded Ni (111) diffraction peaks.

The element distribution of Ni-B-400 NP was estimated by EDX elemental mapping (Fig. $3 \mathrm{~b}-\mathrm{e}$ ). It is seen that Ni is mainly distributed in the core, while $\mathrm{O}$ is concentrated and present in the outer layer. It is worth noting that the distribution of $\mathrm{B}$ cannot be determined due to the interference from the adventitious carbon [18]. A comparison of the mapping diagrams of Ni-B-400 (Fig. 3) and Ni-B (Fig. S1) reveals a more uniform distribution of $\mathrm{O}$ in Ni-B-400.

The composition and valence states of the elements on the surface of the materials were analyzed by XPS. The valence ratio of the elements can be estimated qualitatively by the peak areas in the photoelectron spectra. The XPS spectra of the Ni-B-400 catalyst show that there are $\mathrm{Ni}, \mathrm{B}$, and $\mathrm{C}$ on the surface of the sample, along with 0 , which is mainly present due to the oxidation of the sample exposed in air (Fig. 4a). In order to investigate the composition and valence distribution of the particles, fine scanning of $\mathrm{Ni}, \mathrm{B}$, and $\mathrm{O}$ was carried out. Fig. $4 \mathrm{~b}$ is the fine spectrum of $\mathrm{Ni}$ in Ni-B-400. The characteristic peaks at 856.56 and $874.50 \mathrm{eV}$, with satellite peaks at 861.73 and $880.60 \mathrm{eV}$, could be assigned to the $\mathrm{Ni} 2 p_{3 / 2}$ and $2 p_{1 / 2}$ energy levels of $\mathrm{Ni}^{2+}$ in $\mathrm{Ni} 2 p$. The peak at $852.94 \mathrm{eV}$ corresponds to the $\mathrm{Ni} 2 p_{3 / 2}$ core level of a $\mathrm{Ni}^{0}$ species $[17,19,29,30]$. Comparing with the characteristic peaks of $\mathrm{Ni}$ in other materials (Table $\mathrm{S} 2)$, the binding energy of $\mathrm{Ni}$ in Ni-B-400 increases slightly,

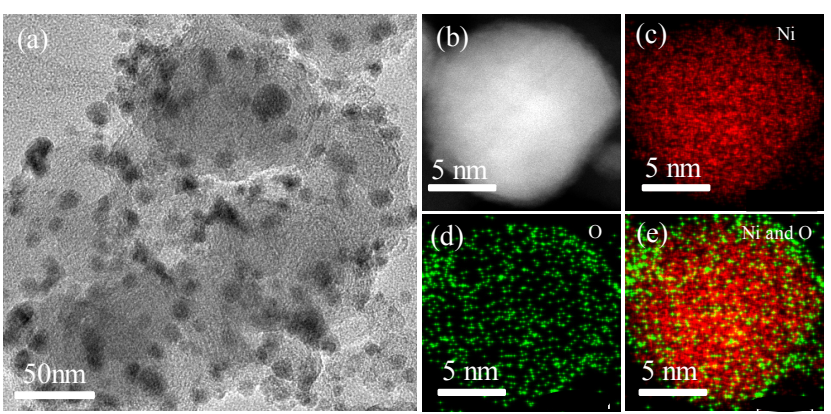

Fig. 3. (a) TEM image and (b) HAADF-STEM image of Ni-B-400; elemental mapping of (c) Ni, (d) $\mathrm{O}$, and (e) $\mathrm{Ni}$ and $\mathrm{O}$ in $\mathrm{Ni}-\mathrm{B}-400$. indicating that the electron density decreases. Additionally, the $\mathrm{Ni}^{0} / \mathrm{Ni}^{2+}$ ratio can significantly account for the electrocatalytic HER $[31,32]$. The ratio of $\mathrm{Ni}^{0}$ and $\mathrm{Ni}^{2+}$ species is reckoned from the fitted peak area.

The $\mathrm{Ni}^{0} / \mathrm{Ni}^{2+}$ ratios in $\mathrm{Ni}-\mathrm{B}, \mathrm{Ni}-\mathrm{B}-300, \mathrm{Ni}-\mathrm{B}-400$, and Ni-B-500 are calculated to be $0.06,0.21,0.28$, and 0.25 , respectively (Table S2). The characteristic peak at $192.98 \mathrm{eV}$ is corresponding to $\mathrm{B} 1 s$, probably from the amorphous $\mathrm{B}_{2} \mathrm{O}_{3}$. The binding energy of $\mathrm{B}$ in Ni-B-400 increases slightly in comparison with other materials (Figs. S3c, S4c, and S5c), indicating that the electron density of $\mathrm{B}$ decreases significantly, and the electrons of $\mathrm{B}$ are more biased toward $\mathrm{Ni}$ or $\mathrm{O}$. The peaks of $\mathrm{O}$ $1 s$ at 532.45 and $531.42 \mathrm{eV}$ correspond to $\mathrm{B}_{2} \mathrm{O}_{3}$ and Ni-O-B, respectively [29]. $\mathrm{B}$ was detected in the XPS, but not in EDX elemental mapping. Combining XPS data and EDX elemental mapping analysis, it can be inferred that the catalysts possess a structure with a metal core and $\mathrm{Ni}-\mathrm{O}-\mathrm{B}$ and $\mathrm{B}_{2} \mathrm{O}_{3}$ shells.

The polarization curves of Ni-B samples were measured in 1 mol L-1 KOH (Fig. 5a). The overpotentials of the materials at 10 $\mathrm{mA} \mathrm{cm}{ }^{-2}$ were $104,119,123,114$, and $146 \mathrm{mV}$ for $\mathrm{Ni}-\mathrm{B} / \mathrm{C}$, Ni-B/C-200, Ni-B/C-300, Ni-B/C-400, and Ni-B/C-500, respectively. At $40 \mathrm{~mA} \mathrm{~cm}^{-2}$, the overpotentials of the materials were 281, 257, 237, 215, and $289 \mathrm{mV}$, respectively (Fig. 5c). After annealing, the materials show a relatively small overpotential at large current. The measured double-layer capacitance $\left(C_{\mathrm{dl}}\right)$ values were $8.0,6.6,7.2,8.1$, and $6.8 \mathrm{mF} \mathrm{cm}^{-2}$ for $\mathrm{Ni}-\mathrm{B}$, Ni-B-200, Ni-B-300, Ni-B-400, and Ni-B-500, respectively (Fig. S6). The values of $C_{\mathrm{dl}}$ change with a change in temperature, as shown in Fig. S6f. Ni-B is amorphous and has a large $C_{\mathrm{dl}}$, which can explain its high activity at low potential. However, at high potential, the inappropriate proportion of $\mathrm{Ni}^{2+}$ and $\mathrm{Ni}^{0}$ on the surface is not conducive for the process of hydrogen evolution, because of which the activity decreases. After annealing, the $C_{\mathrm{dl}}$ decreases slightly, possibly due to the transformation of the amorphous material into $\mathrm{Ni}$ crystals. With the increase in calcining temperature, the surface structure of the materials changes, as revealed in the XPS analysis, and the $C_{\mathrm{dl}}$ slightly 

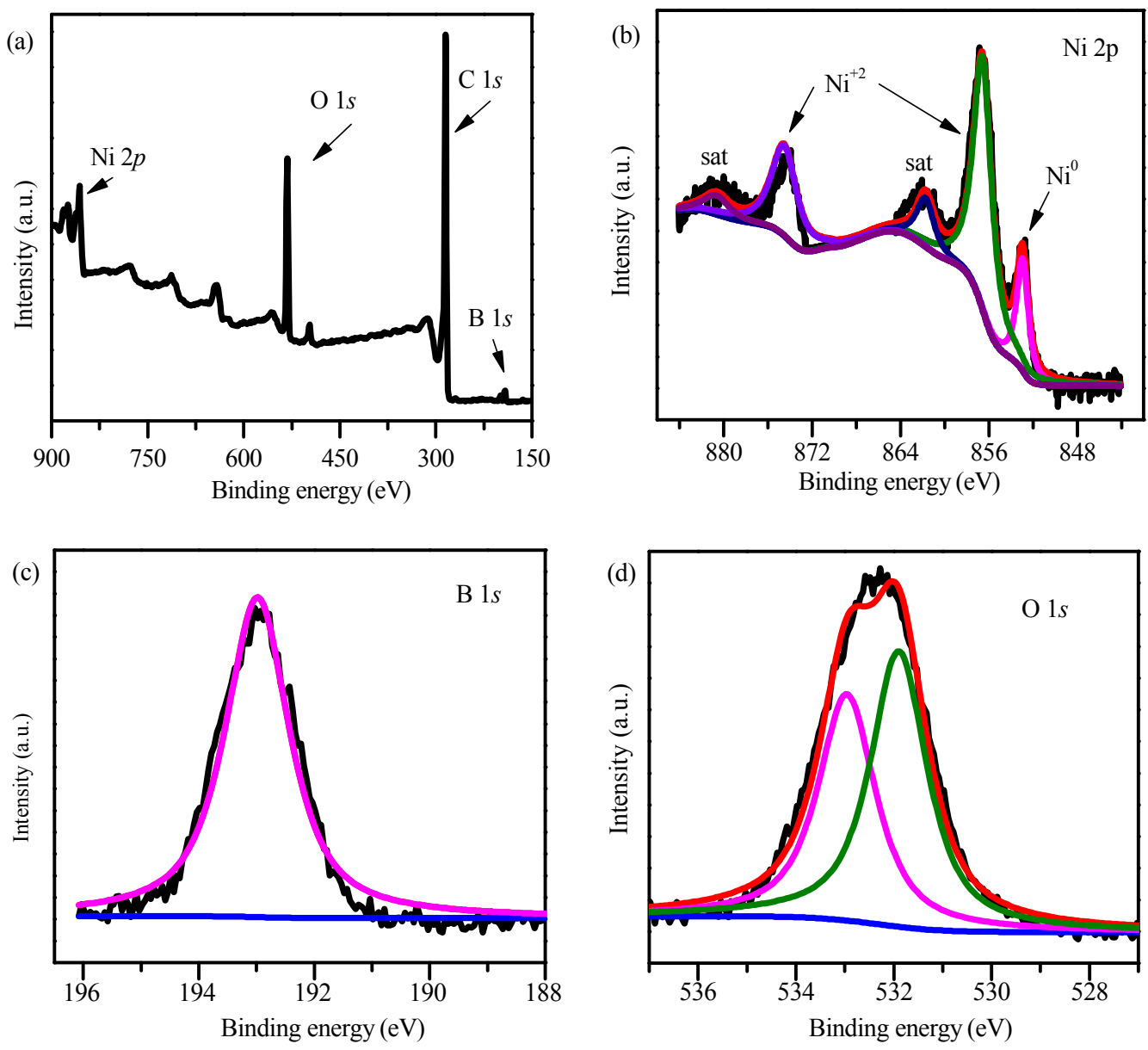

Fig. 4. (a) The full scan XPS spectrum; (b) Ni 2p, (c) B 1s, and (d) 0 1s XPS spectra of Ni-B-400.

increases. The results of the TGA suggest that the material residues are basically stable after $650{ }^{\circ} \mathrm{C}$, and the proportions of the remaining $\mathrm{NiO}$ are $48.03 \%, 50.77 \%, 52.21 \%, 52.81 \%$, and $55.01 \%$, respectively. The $\mathrm{Ni}$ contents were calculated to be $42.06 \%, 44.76 \%, 46.18 \%, 46.78 \%$, and $48.99 \%$, respectively (Fig. S7). According to the loading of the catalyst and the $\mathrm{Ni}$ content in the catalyst, the mass-normalized current density at an overpotential of $200 \mathrm{mV}$ of the catalyst was calculated (Fig. $5 b)$. This is basically consistent with the change in the trend of $C_{\mathrm{dl}}$. By comparison, it is found that amorphous Ni-B particles exhibit a large $C_{\mathrm{dl}}$ value, but due to the lack of an active site with higher catalytic activity, the inherent hydrogen evolution current is small. Upon increasing the annealing temperature to $500{ }^{\circ} \mathrm{C}$, the particles of the materials become larger, and the specific surface area decreases. This becomes the main decisive factor affecting the hydrogen evolution activity of the material and the decrease in the mass-normalized current density.

Tafel plots were calculated to understand the mechanism and the rate determining step of the HER in the presence of these samples [33,34]. In the low overpotential region, the

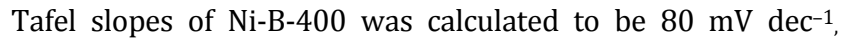
which was lower than that of Ni-B (114 $\mathrm{mV} \mathrm{dec} \mathrm{cm}^{-1}$ ) (Fig. $5 \mathrm{~d}$ ), suggesting that the rate determining step is the discharge reaction (Volmer step) or the $\mathrm{H}$ desorption from the surface of the catalyst. The results reported previously $[36,37]$ suggest that hydroxide has a high electron density. Due to the strong electron affinity, it can be adsorbed by $\mathrm{Ni}^{2+}$ ions, which have a low electron density. Nickel atoms near $\mathrm{Ni}^{2+}$ can adsorb hydrogen atoms, imparting a synergistic HER catalytic activity of $\mathrm{Ni}^{2+} / \mathrm{Ni}^{0}$. The results of XPS confirmed the $\mathrm{Ni}^{2+}-\mathrm{Ni}$ structure (Table S2), and the dominant form of $\mathrm{Ni}$ on the material surface was $\mathrm{Ni}^{2+}$. So, a certain amount of $\mathrm{Ni}^{0}$ is important for a favorable $\mathrm{H}$ adsorption. Therefore, we speculated that Ni-B-400 has the appropriate proportion of $\mathrm{Ni}^{0} / \mathrm{Ni}^{2+}$, and therefore, it has the best activity for the electrocatalytic hydrogen evolution. Surprisingly, the HER activity of Ni-B-400 in the basic media was outstanding in contrast to other noble metal-free HER electrocatalysts listed in Table S3.

Stability is an important parameter for HER catalysts [38]. Here, LSV measurement after 3000 cycling between -0.2 and $0.2 \mathrm{~V}$ (vs RHE) at a scan rate of $200 \mathrm{mV} \mathrm{s}^{-1}$ was performed to evaluate the stability of the Ni-B-400 catalyst (Fig. 6a). The results show that Ni-B-400 exhibits excellent durability in 1 mol L-1 $\mathrm{KOH}$ with $21 \mathrm{mV}$ over potential increasing at $40 \mathrm{~mA}$ $\mathrm{cm}^{-2}$. The XRD results of Ni-B-400 before and after the cycling measurements on the carbon cloth are illustrated in Fig. 6b. By comparing the XRD data before and after the test, the positions of the peaks are found to shift slightly to the higher angles, 

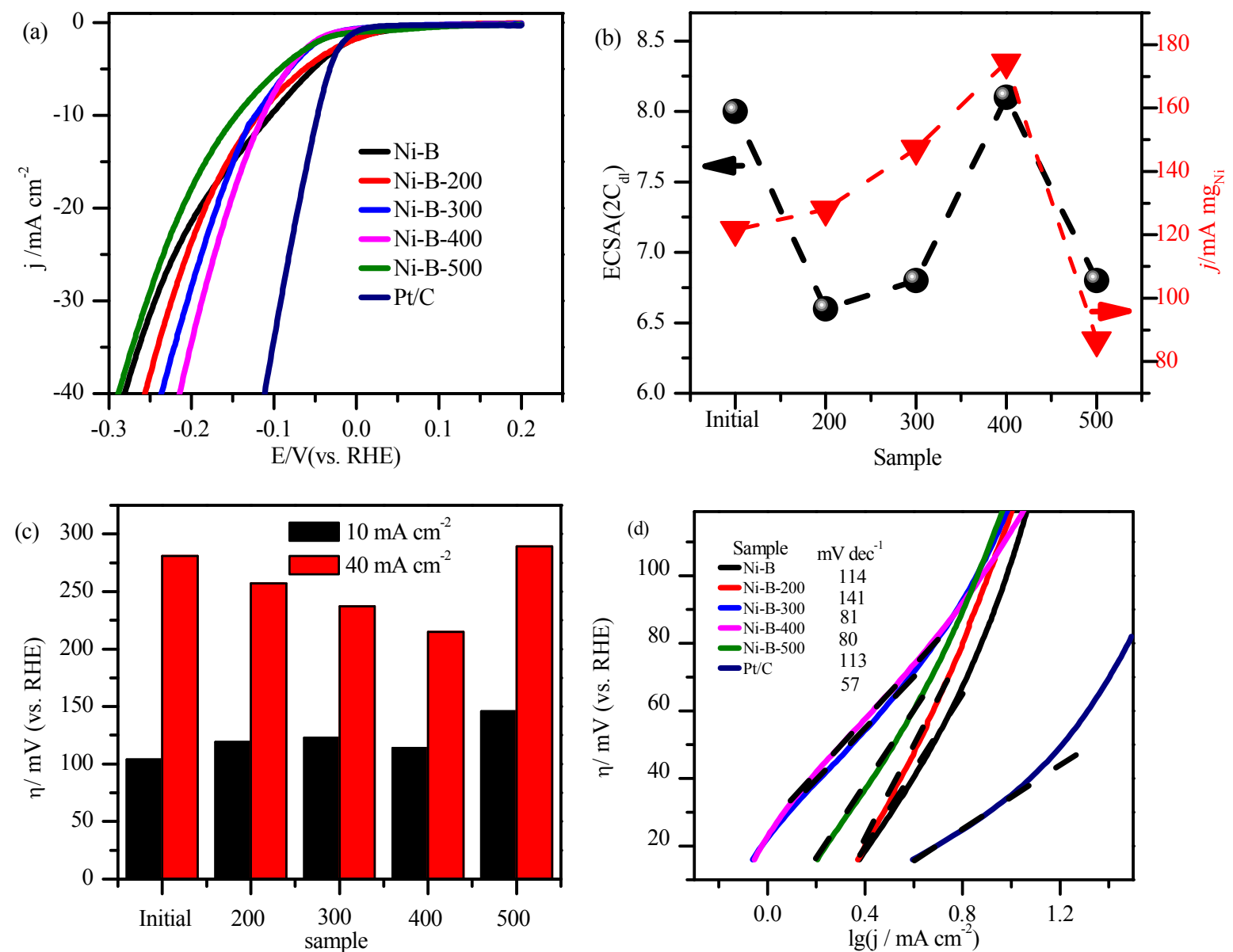

Fig. 5. (a) The polarization curves of Ni-B, Ni-B-200, Ni-B-300, Ni-B-400, Ni-B-500, and Pt/C; (b) ESCA ( $\left.2 C_{\mathrm{dl}}\right)$ for the respective Ni-B series and current densities at an overpotential of $200 \mathrm{mV}$ plotted against the load of nickel in the respective Ni-B series; (c) The overpotential of the catalysts at 10 and $40 \mathrm{~mA} \mathrm{~cm}^{-2}$; (d) Tafel plots derived from (a).
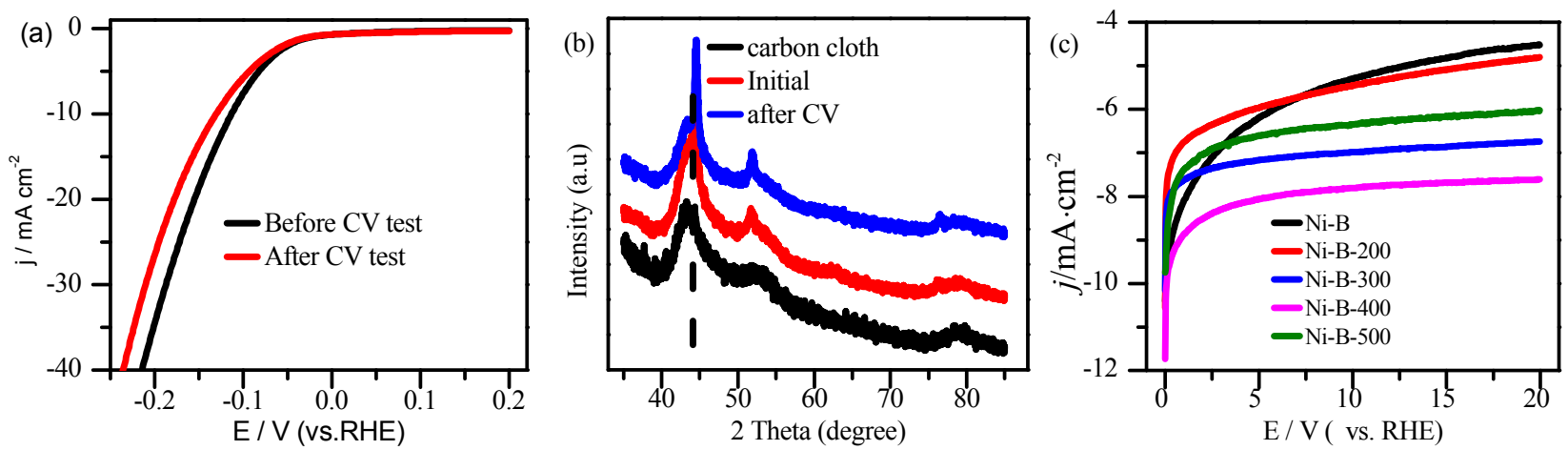

Fig. 6. (a) Durability tests for Ni-B-400 by CV scanning for 3000 cycles in $1 \mathrm{~mol} \mathrm{~L}^{-1} \mathrm{KOH}$; (b) XRD patterns of Ni-B-400 after CV scanning in 1 mol L-1 $\mathrm{KOH}$ for 3000 cycles; (c) Current densities at various times at an overpotential of $150 \mathrm{mV}$.

suggesting a slight lattice contraction. The lattice of Ni-B expands to a certain extent, and the catalyst possesses good catalytic activity.

The XRD data after CV scanning suggest that the lattice of $\mathrm{Ni}$ shrinks, while the activity of the catalyst decreases (Table S4). ICP-OES indicated a B/Ni atomic ratio of 0.897 after the $\mathrm{CV}$ test, which is smaller than the original ratio of 0.934 (Supporting Information). It can be inferred that the loss of B in the catalytic process leads to the lattice shrinkage and the decrease of catalytic hydrogen evolution activity. In order to simulate an industrial production, the corresponding time-urrent curve was obtained under a potential of $150 \mathrm{mV}$. Remained current densities of 4.52, 4.80, 6.74, 7.62, and $6.02 \mathrm{~mA} \mathrm{~cm}^{-2}$ for Ni-B, Ni-B-200, Ni-B-300, Ni-B-400, and Ni-B-500, respectively, were obtained during the $20 \mathrm{~h}$ stability test, confirming the excellent durability of Ni-B-400 (Fig. 6c). 


\section{Conclusions}

Ni-B electrocatalysts were synthesized by the chemical reduction-annealing process. During the annealing process, $\mathrm{Ni}$ forms an alloy with $\mathrm{B}$, which regulates the electronic structure of $\mathrm{Ni}$. At the same time, an appropriate ratio of $\mathrm{Ni}^{0}$ and $\mathrm{Ni}^{2+}$ can be obtained, which is conducive for the entire process of HER and a better activity of hydrogen evolution. The Ni-B-400 electrocatalysts display excellent HER performance in $1 \mathrm{~mol} \mathrm{~L}^{-1}$ $\mathrm{KOH}$ with a small overpotential of $114 \mathrm{mV}$ at $10 \mathrm{~mA} \mathrm{~cm}^{-2}$, low Tafel slope of $80 \mathrm{mV} \mathrm{dec}^{-1}$, and high electrochemical durability. The excellent electrocatalytic HER performance of Ni-B-400 can be as attributed to the following reasons: a proper lattice expansion; an appropriate proportion of $\mathrm{Ni}^{0} / \mathrm{Ni}^{2+}$; and the $\mathrm{Ni}-\mathrm{B}$ alloy obtained by the annealing treatment that has more stable structure and performance, so that a long-term stability in hydrogen evolution is maintained.

\section{Acknowledgments}

This work was supported by the National Natural Science Foundation of China (21573083), the 1000 Young Talent (to Deli Wang), and initiatory financial support from Huazhong University of Science and Technology (HUST). The authors thank the Analytical and Testing Center of HUST for allowing use of its facilities.

\section{References}

[1] M. Ledendecker, J. S. Mondschein, O. Kasian, S. Geiger, D. Göhl, M. Schalenbach, A. Zeradjanin, S. Cherevko, R. E. Schaak, K. Mayrhofer, Angew. Chem. Int. Ed., 2017, 56, 9767-9771.

[2] J. Wang, F. Xu, H. Jin, Y. Chen, Y. Wang, Adv. Mater., 2017, 29, 1605838.

[3] J. Wang, H. Zhang, X. Wang, Small Methods, 2017, 1, 1700118.

[4] L. Xu, Q. Jiang, Z. Xiao, X. Li, J. Huo, S. Wang, L. Dai, Angew. Chem. Int. Ed., 2016, 55, 5277-5281.

[5] Z. Xiao, Y. Wang, Y. C. Huang, Z. Wei, C. L. Dong, J. Ma, S. Shen, Y. Li, S. Wang, Energy Environ. Sci., 2017, 10, 2563-2569.

[6] F. Yang, Y. Zhao, Y. Du, Y. Chen, G. Cheng, S. Chen, Wei Luo, Adv. Energy Mater., 2018, 8, 1703489.

[7] W. Xu, H. Wang, Chin. J. Catal., 2017, 38, 991-1005.
[8] K. Xia, J. Guo, C. Xuan, T. Huang, Z. Deng, L. Chen, D. Wang, Chin. Chem. Lett., 2019, 30, 192-196.

[9] Y. Ito, T. Ohto, D. Hojo, M. Wakisaka, Y. Nagata, L. Chen, K. Hu, M. Izumi, J. I. Fujita, T. Adschiri, ACS Catal., 2018, 8, 3579-3586.

[10] V. Vij, S. Sultan, A. M. Harzandi, A. Meena, J. N. Tiwari, W. G. Lee, T. Yoon, K. S. Kim, ACS Catal., 2017, 7, 7196-7225.

[11] M. Gong, W. Zhou, M. C. Tsai, J. Zhou, M. Guan, M. C. Lin, B. Zhang, Y. Hu, D. Y. Wang, J. Yang, S. J. Pennycook, B. J. Hwang, H. Dai, Nat. Commun., 2014, 5, 4695.

[12] X. Yan, L. Tian, X. Chen, J. Power Sources, 2015, 300, 336-343.

[13] L. Yan, H. Jiang, Y. Xing, Y. Wang, D. Liu, X. Gu, P. Dai, L. Li, X. Zhao, J. Mater. Chem. A, 2018, 6, 1682-1691.

[14] E. J. Popczun, J. R. McKone, C. G. Read, A. J. Biacchi, A. M. Wiltrout, N. S. Lewis, R. E. Schaak, J. Am. Chem. Soc., 2013, 135, 9267-9270.

[15] J. J. Lv, J. Zhao, H. Fang, L. P. Jiang, L. L. Li, J. Ma, J. J. Zhu, Small, 2017, 13, 1700264.

[16] Y. Ge, S. P. Gao, P. Dong, R. Baines, P. M. Ajayan, M. Ye, J. Shen, Nanoscale, 2017, 9, 5538-5544.

[17] P. Zhang, M. Wang, Y. Yang, T. Yao, H. Han, L. Sun, Nano Energy, 2016, 19, 98-107.

[18] J. Jiang, M. Wang, W. Yan, X. Liu, J. Liu, J. Yang, L. Sun, Nano Energy, 2017, 38, 175-184.

[19] J. Masa, I. Sinev, H. Mistry, E. Ventosa, M. de la Mata, J. Arbiol, M. Muhler, B. Roldan Cuenya, W. Schuhmann, Adv. Energy Mater., 2017, 7, 1700381.

[20] S. Lu, D. Cao, X. Xu, H. Wang, Y. Xiang, RSC Adv., 2014, 4, 26940-26945.

[21] W. Lu, T. Liu, L. Xie, C. Tang, D. Liu, S. Hao, F. Qu, G. Du, Y. Ma, A. M. Asiri, X Sun, 2017, Small, 13, 1700805.

[22] M. Ma, F. Qu, X. Ji, D. Liu, S. Hao, G. Du, A. M. Asiri, Y. Yao, L. Chen, X. Sun, Small, 2017, 13, 1700394.

[23] M. Ma, D. Liu, S. Hao, R. Kong, G. Du, A. M. Asiri, Y. Yao, X. Sun, Inorg. Chem. Front., 2017, 40, 840-844.

[24] C. Lai, J. Wang, W. Lei, C. Xuan, W. Xiao, T. Zhao, T. Huang, L. Chen, Y. Zhu, D. Wang, ACS Appl. Mater. Interfaces, 2018, 10, 38093.

[25] G. Yanalak, A. Aljabour, E. Aslan, F. Ozel, I. H. Patir, M. Kus, M. Erso, Electrochim. Acta, 2018, 291, 311-318.

[26] J. Yin, Q. Fan, Y. Li, F. Cheng, P. Zhou, P. Xi, S. Sun, J. Am. Chem. Soc., 2016, 138, 14546-14549.

[27] J. Zheng, Z. Zhuang, B. Xu, Y. Yan, ACS Catal., 2015, 5, 4449-4455.

[28] Z. Y. Wu, W. B. Ji, B. C. Hu, H. W. Liang, X. X. Xu, Z. L. Yu, B. Y. Li, S. H. Yu, Nano Energy, 2018, 51, 286-293.

[29] W. J. Jiang, S. Niu, T. Tang, Q. H. Zhang, X. Z. Liu, Y. Zhang, Y. Y. Chen, J. H. Li, L. Gu, L. J. Wan, J. S. Hu, Angew. Chem. Int. Ed., 2017,

\section{Graphical Abstract}

Chin. J. Catal., 2019, 40: 1867-1873 doi: S1872-2067(19)63331-0

\section{Ultrafine Ni-B nanoparticles for efficient hydrogen evolution reaction}

Ting Huang, Tao Shen, Mingxing Gong, Shaofeng Deng, Chenglong Lai, Xupo Liu, Tonghui Zhao, Lin Teng, Deli Wang*

Huazhong University of Science and Technology

Ultrafine Ni-B nanoparticles can improve the reaction rate and efficiency of the electrocatalytic hydrogen evolution to produce high-purity hydrogen.

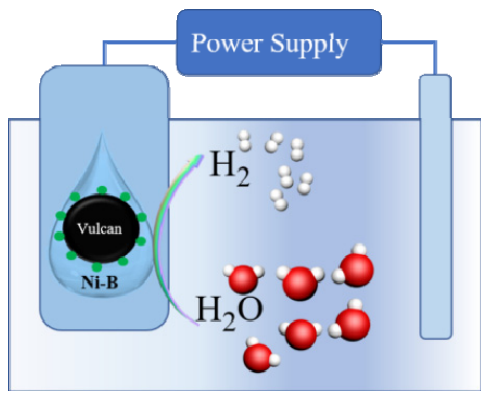


$56,6572-6577$.

[30] T. Sun, L. Xu, Y. Yan, A. A. Zakhidov, R. H. Baughman, J. Chen, ACS Catal., 2016, 6, 1446-1450.

[31] J. Du, L. Wang, L. Bai, P. Zhang, A. Song, G. Shao, ACS Sustain. Chem. Eng., 2018, 6, 10335-10343.

[32] J. Wang, S. Mao, Z. Liu, Z. Wei, H. Wang, Y. Chen, Y. Wang, ACS Appl. Mater. Interfaces, 2017, 9, 7139-7147.

[33] Z. Sun, W. Fan, T. Liu, Electrochim. Acta, 2017, 250, 91-98.

[34] J. Xu, T. Liu, J. Li, Y. Liu, B. Zhang, D. Xiong, I. Amorim, W. Li, L. Liu, Energy Environ. Sci., 2018, 11, 1819-1827.

[35] Z. Cai, A. Wu, H. Yan, Y. Xiao, C. Chen, C. Tian, L. Wang, R. Wang, H. Fu, Nanoscale, 2018, 10, 7619-7629.

[36] T. Wang, R. Jin, X. Wu, J. Zheng, X. Li, K. Ostriko, J. Mater. Chem. A, 2018, 6, 9228-9235.

[37] Y. Zhu, T. Liu, L. Li, S. Song, R. Ding, Ionics, 2018, 24, 1121-1127.

[38] R. Subbaraman, D. Tripkovic, K. C. Chang, D. Strmcnik, A. P. Pauli- kas, P. Hirunsit, M. Chan, J. Greeley, V. Stamenkovic, N. M. Markovic, Nat. Mater., 2012, 11, 550-557.

[39] H. Vrubel, X. Hu, Angew. Chem. Int. Ed., 2012, 51, 12703-12706.

[40] J. Masa, P. Weide, D. Peeters, I. Sinev, W. Xia, Z. Sun, C. Somsen, M. Muhler, W. Schuhmann, Adv. Energy Mater., 2016, 6, 1502313.

[41] H. Li, P. Wen, Q. Li, C. Dun, J. Xing, C. Lu, S. Adhikari, L. Jiang, D. L. Carroll, S. M. Geyer, Adv. Energy Mater., 2017, 7, 1700513.

[42] Q. Ma, C. Hu, K. Liu, S. F. Hung, D. Ou, H. M. Chen, G. Fu, N. Zheng, Nano Energy, 2017, 41, 148-153.

[43] C. Tang, N. Cheng, Z. Pu, W. Xing, X. Sun, Angew. Chem. Int. Ed., 2015, 54, 9351-9355.

[44] J. Tian, Q. Liu, A. M. Asiri, X. Sun, J. Am. Chem. Soc., 2014, 136, 7587-7590.

[45] X. Chen, Z. Yu, L. Wei, Z. Zhou, S. Zhai, J. Chen, Y. Wang, Q. Huang, E. Karahan, X. Liao, Y. Chen, J. Mater. Chem. A, 2019, 7, 764-774.

\title{
超小Ni-B纳米颗粒的合成与电催化性能研究
}

\author{
黄 亭, 申 涛, 龚明星, 邓邵峰, 赖成龙, 刘旭坡, 赵桐辉, 滕 林, 王得丽* \\ 华中科技大学化学与化工学院, 能量转换与存储材料化学教育部重点实验室, \\ 材料化学与服役失效湖北省重点实验室, 湖北武汉 430074
}

\begin{abstract}
摘要: 寻找活性高、稳定性好、成本低廉的氢析出反应电催化剂是氢析出反应的最佳选择, 故析氢催化剂的探究受到广泛 关注. 贵金属 $\mathrm{Pt}$ 基、Ir基和 $\mathrm{Ru}$ 基等催化剂具有优异的析氢催化活性以及稳定性, 但贵金属的价格和储量问题导致其一直无 法商业化应用. 金属镍具有类Pt的电子结构, 故将镍基材料应用于电催化析氢反应受到格外的重视. 本文采用简单易行的 化学还原-退火两步法合成了负载在Vulcan上的 Ni-B纳米颗粒. XRD表征表明, 㷽烧前的 Ni-B/C材料在 $45.36^{\circ}$ 处有一个针 峰, 说明材料为无定形态, 在 $25.21^{\circ}$ 处为碳材料(002)晶面的峰. 退火后处理的样品Ni-B-200、Ni-B-300、Ni-B-400和Ni-B-500 在 $45^{\circ} 、 52^{\circ}$ 和 $76^{\circ}$ 左右有三个明显的峰, 通过对比标准卡片(JCDPS87-0712)发现其分别归属于Ni的(111)、(200)和(220)晶面. 随着温度的升高, 特征峰向低角度略有偏移, 表现出镍的晶格略有扩张, 可能是 $\mathrm{B}$ 进入 $\mathrm{Ni}$ 晶格间隙造成的. 从催化剂 $\mathrm{Ni}-\mathrm{B}$ 、

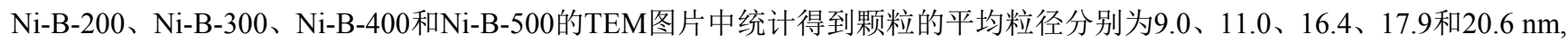
说明随着温度的升高, Ni-B颗粒逐渐变大, 且与根据XRD数据通过谢乐公式计算得到的各催化剂晶粒粒径大小的结果基本 一致. XPS测试表明, 相比于其他材料 $\mathrm{Ni}$ 的特征峰, Ni-B-400中 Ni的键能向高的方向偏移, 电子密度下降, 有利于在析氢过 程中吸附含氧物种, 加快催化过程中的Volmer步骤, 从而提高催化剂的析氢活性. 样品 $\mathrm{Ni}-\mathrm{B} / \mathrm{C}-400$ 的 $\mathrm{Ni}^{2+}$ 峰面积与 $\mathrm{Ni}^{0}$ 峰面 积的比值, 为 3.5 , 小于其他材料, 表明该炦烧温度下能够得到具有更高比例单质 $\mathrm{Ni}$ 的材料, 该结构有利于吸附氢原子, 以便 完成整个析氢过程. 结合XPS、XRD及TEM表征可以推断, 催化剂具有金属的核和 $\mathrm{NiO}$ 和 $\mathrm{B}_{2} \mathrm{O}_{3}$ 的壳层, 为核壳结构. 在 1 $\mathrm{mol} / \mathrm{L} \mathrm{KOH}$ 析氢测试中, 催化剂Ni-B、Ni-B-200、Ni-B-300、Ni-B-400和Ni-B-500析氢电流密度达到 $10 \mathrm{~mA} / \mathrm{cm}^{2}$ 所需的过电 位分别为 $104,119,123,114$ 和 $146 \mathrm{mV}$; 达到 $40 \mathrm{~mA} / \mathrm{cm}^{2}$ 所需过电位为 $281 、 257 、 237 、 215$ 和 $289 \mathrm{mV}$. 在这些催化剂中, Ni-B/C-400表现出最优的HER 性能, 达到 $40 \mathrm{~mA} / \mathrm{cm}^{2}$ 时过电位为 $215 \mathrm{mV}$, 最低的 Tafel斜率 $80 \mathrm{mV} / \mathrm{dec}$, 电化学耐久性高. Ni-B-400的高电催化HER性能可归因于以下几方面: 一定的晶格膨胀; 合适的 $\mathrm{Ni}^{0} / \mathrm{Ni}^{2+}$ 配比; 其结构较稳定, 可以长期维持 析氢稳定性.
\end{abstract}

关键词: Ni-B; 非贵金属电催化剂; 析氢反应; 超细纳米颗粒; 碱性电解质

收稿日期: 2019-01-27. 接受日期: 2019-03-04. 出版日期: 2019-12-05.

*通讯联系人. 电子信箱: wangd181125@hust.edu.cn

基金来源: 国家自然科学基金(21573083).

本文的电子版全文由Elsevier出版社在ScienceDirect上出版(http://www.sciencedirect.com/science/journal/18722067). 